\title{
House Prices And Current ACCount Imbalances IN OECD COUNTRIES
}

\author{
Philip Arestis, University of Cambridge, UK \\ Ana Rosa Gonzalez-Martinez, Cambridge Econometrics, UK
}

\begin{abstract}
This contribution attempts to provide theoretical propositions and empirical evidence on the 'obscure' relationship between current account imbalances and house prices. We propose a theoretical framework, which studies the interaction between house prices and current account imbalances and also pays special attention to the role played by fiscal and monetary policies. In a second stage of this contribution, our theoretical framework is estimated empirically by using data from 17 OECD economies, which spans the period 1970-2013. In doing so, the least squares technique with breakpoints is employed.
\end{abstract}

Keywords: House Prices, Current Account Imbalances, Taxation, Monetary Policy, OECD Countries

JEL Classification: C22, R31. 


\section{Introduction}

This contribution attempts to provide a theoretical framework and empirical evidence for a better understanding of the 'obscure' relationship between current account imbalances and house prices. The interest in this relationship has been increasing since the aftermath of the August 2007 financial crisis. However, the economic debate has not reached an agreed position regarding the direction of causality between these two variables, namely, current account imbalances and house prices.

The burst of the 2006/07 housing bubble in the US and the 'great recession' that emerged subsequently in the world economy have had further relative effects. In this context, the links between the housing market and the financial system have become stronger, and the analysis of the determinants of the behaviour of the housing market is the key to our understanding of the evolution of house price dynamics. Moreover, there are some variables under the control of the fiscal and monetary authorities, which cannot be ignored in this analysis since they can be used to understand the evolution of house prices, i.e. mortgageeligibility criteria and taxation on property.

One feature of the evolution of the housing market, which has been revealed as a key one after the occurrence of several episodes of booms and busts in the housing markets, is the synchronization of the housing cycles. Real estate assets are just tradable in local markets, which intuitively suggest the lack of correlation among house prices in different markets. However, some contributors, such as Cesa-Bianchi (2012), suggest, as an alternative explanation, the presence of co-movements in the fundamentals of the housing markets: interest rates, economic development, demographics, technological change, and wars. In other words, it is the existence of the same trends in the evolution of credit standards and correlated housing risk premia. ${ }^{1}$ In view of this synchronisation, housing literature has turned to new cross-country studies, which revisit the basic dynamics of the housing market and estimate single behavioural equations in an attempt to capture the peculiarities of each market.

Our contribution benefits from the inclusion of current account imbalances in our testable hypothesis whose role in this market still remains unclear. In addition to that, an important characteristic of our econometric analysis is that it accounts explicitly for the existence of structural breaks in the estimated parameters, which are determined endogenously.

\footnotetext{
${ }^{1}$ Also, Renaud (1995) considers that the synchronised housing cycle, which took place during the period 19851994 in some OECD countries, was due to financial liberalization. Otrok and Terrones (2005) consider, as explanatory variables of these common movements, interest rates and economic activity.
} 
We begin with the determination of a house price equation, sufficiently general, which captures the traditional determinants like real disposable income, the real long-run interest rate and bank credit, in addition to current account imbalances. This is enhanced by taking on board several further indicators, which permit us to account for the role of the public sector in the economies under consideration. Subsequently, this theoretical proposition is subjected to empirical investigation over the period 1970 to 2013 in 17 OECD countries by means of the least squares technique with breakpoints (EViews, 2013). The justification to estimate single behavioural equations is that since the emergence of the financial crisis of August 2007, the effects of the collapse of the housing markets are not homogeneous among the main economies (The Economist, 2012).

The layout of the rest of this contribution is as follows. Section 2 presents our theoretical framework. Section 3 discusses the econometric technique and the data employed to test empirically our testable hypothesis. Section 4 presents the main findings of our empirics. Further discussion of our empirical results is undertaken in Section 5. Finally, section 6 summarizes and concludes.

\section{A Theoretical Model of House Prices}

In order to elaborate on our theoretical framework, we assume that house prices are the result of the interaction between the demand and supply of housing. More specifically, the following equation encapsulates the determinants of the demand for housing in our framework:

$$
D^{H}=D^{H}\left(P^{H}, \mathrm{Y}, i_{h}, B^{C}, \Gamma, C^{A B}\right)
$$

where the demand for housing, $D^{H}$, is positively related to real disposable income, $Y^{\prime}$, and the volume of loans to acquire dwellings, $B^{C}$. Equation (1) also captures a negative relationship between the demand for housing and house prices, $P^{H}$. Moreover, the demand for housing is negatively related to the mortgage rate, $i_{h}$; the ratio of taxation on property over house prices, $\Gamma$; and, most importantly for the purposes of this contribution, the current account balance, $C^{A B} \cdot 2$

The demand for housing is influenced by the interaction of domestic and international economies since developed ones are far from being closed systems. In this sense the current

\footnotetext{
${ }^{2}$ The sign below a variable indicates the partial derivative of the demand for housing with respect to that variable.
} 
account becomes an important variable in equation (1). Housing demand and households' consumption are connected in view of common drivers, as for example, disposable income or expectations about the evolution of demand in the near future. ${ }^{3}$ Moreover, the degree of openness of the economy will play an important role on how household's consumption and demand for construction inputs can be satisfied. Equation (1) also suggests that any macroeconomic shocks, which affect income, have a positive impact on housing demand. This is so since housing becomes more affordable. Moreover, housing affordability is also determined by house prices, which are also included in equation (1). Apart from that, the existence of a well-developed credit market where agents can obtain those loans that are needed for the purchase to take place, exerts a positive effect on the demand for housing. Furthermore, an important aspect of equation (1) is that it acknowledges the existence of market failures, which require the intervention of public authorities in this market. Market failures emanate in circumstances of extremely high house prices, which are caused by investors' speculation and could 'expunge' potential credit-worthy buyers from the market. These solvent buyers do not have the chance to decide if they wish to enter or not in the housing market. Avoiding this phenomenon taking place is paramount since the consumption of housing services is a basic need. In this context, public authorities could prevent this from happening if they curb housing demand for speculative purposes. ${ }^{4}$

In order to account fully for both sides of the housing market, we hypothesise that the supply of housing, $S^{H}$, is positively related to house prices, as in equation (2):

$$
\begin{array}{r}
S^{H}=S^{H}\left(P^{H}, R^{R I}, i_{P}\right) \\
+\quad+\quad-
\end{array}
$$

where the variables are as defined above, with the exception of $i_{P}$, which is the interest rate that property developers face when obtaining finance, and is required to develop their activities; and $R^{R I}$, which stands for real residential investment.

The rationale behind our proposed housing supply equation is that any shock in the housing market, which introduces disequilibrium between the supply and the demand for housing and terminates in rising house prices, produces an increase in the supply of

\footnotetext{
${ }^{3}$ Punzi (2013) points to a negative correlation between current account and housing variables. Utilizing a twocountry DSGE model, Punzi (op. cit.) argues that the 'wealth' effect, which emanates from rising house prices, boosts domestic consumption, in view of getting into debt becoming easier, thereby contributing to a current account deficit. Aizenman and Jinjarak (2009) also identify a negative correlation between real estate prices and current account.

${ }^{4}$ In order to implement the policy referred to in the text, policy makers can use several types of regulation or different types of taxation. For the purpose of this contribution, we focus on the role played by taxation on property.
} 
properties that are available in the market via two different channels. On the one hand, the increase in prices is understood by property developers as an indicator of the existence of extraordinary profits. In other words, in the context of a strong preference for house prices we can expect that property developers increase residential demand, i.e. increase the flow of new properties, which become available. On the other hand, in the context characterised by rising house prices, some home owners see their current stock of housing as a source of potential capital gains and decide to put their properties in the market. Apart from that, when strong pressure on house prices is evident some individuals decide to rent their properties and move into other units, which are more suitable to them due to price or physical characteristics. The behaviour of this group of home owners has an impact on rental prices, which eventually affects house prices. Finally, our supply of housing relationship also accounts for the impact of interest rates. This is so since small property developers need to get into debt in order to run their business. To make the point, we may note that in the case of the United Kingdom, small and medium size property developers absorb $99.9 \%$ of the UK's construction businesses (BIS, 2013).

An equilibrium position for this market is reached when demand and supply of housing are equal. The translation of this assumption into our framework is to set equations (1) and (2) equal to each other, and solve for the house-prices variable. As a result, house prices are defined as indicated in equation (3):

$$
P^{H}=P^{H}\left(\mathrm{Y}^{d}, i, R^{R I}, B^{C}, \Gamma, C^{A B}\right)
$$

where the symbols have the same meaning as above.

To begin with the discussion of the fundamentals included in equation (3), we proceed to elaborate on the role played by the main variable of this contribution, namely the current account imbalances, $C^{A B}$, one. The relevant empirical evidence highlights the fact that some countries, which have experienced the highest increase in their house prices, display at the same time large external imbalances (Adam et al., 2011). ${ }^{5}$ This phenomenon can be interpreted in terms of a potential positive relationship between house prices and net foreign inflows. ${ }^{6}$ The general view is that net foreign inflows increase house prices since they can provoke falls in real interest rates, which eventually lead the economy to a position where

\footnotetext{
${ }^{5}$ However, Favilukis et al. (2012) do not find a significant impact of capital flows on house prices from 2002 to 2010 in a sample of several countries.

${ }^{6}$ Benetrix et al. (2011) examine empirically the impact of current account on house prices in two ways. First, they consider the complete cycle, and, second, they focus on this relationship during slumps. Their analysis does not find a significant impact over the cycle, but when prices fall current account surpluses emerge.
} 
house price appreciation is exacerbated by the low cost of getting into debt (Taylor, 2009). On the other hand, an alternative view suggests that a strong and high domestic demand provokes movements in house prices and capital inflows in the same direction (Laibson and Mollerstrom, 2010; Ferrero, 2011). ${ }^{7}$

Our testable hypothesis relates to the latter view. ${ }^{8}$ To begin with, we discuss the most 'intuitive' channels through which the housing market and the current account balance are connected. First of all, we need to take into account the fact that a high level of activity in the construction sector could provoke an increase in imports of those raw materials that are used as inputs for the production process of this particular sector, and also equipment for construction purposes. ${ }^{9}$ Secondly, an additional role of the external sector of an economy, which exhibits an active housing market, can be identified. We refer to the imports of other durable goods whose consumption is related to the acquisition of dwellings, such as the socalled 'white goods'. However, the impact that arises from imports of durable goods is relatively small since their consumption is not a high fraction of the total consumption (Benito et al., 2006). ${ }^{10}$

Moving to the discussion of the 'core' relationship between house prices and the current account balance, we elaborate on an additional phenomenon, which is paramount for understanding this connection. More specifically, in the context of high effective demand, strong preferences for housing and positive expectations about the evolution of house prices, we can expect individuals to go for higher consumption. This is so in view of the existence of the 'wealth' effect, which operates through the economy. In other words, an increase in house prices is interpreted by home owners as an increase in their net wealth, which is one of the main drivers of households' consumption. Eventually, this increase in consumption will exert a positive impact on imports of final and intermediate goods to satisfy households' final demand. The evolution of external trade along the lines described above could also affect the evolution of domestic production and income growth in the economy. ${ }^{11}$ This situation becomes more evident in those countries that show a high propensity to consume, as for example in Spain (Rebollo, 2001).

\footnotetext{
${ }_{8}^{7}$ Favilukis et al. (2012) discuss these alternative views.

${ }^{8}$ Gete (2010) also suggests that an increase in preferences for housing, provoke a relocation of productive inputs toward housing production, which means increasing imports of non-housing goods.

${ }^{9}$ This increase in the volume of imports for this type of commodities can be relevant in the case of the Chinese economy, in which imports of raw materials and equipment almost eliminated its surplus of the current account (BBC, 2013).

${ }^{10}$ Alternatively, Geerolf and Grjebine (2013) propose a model where current account balances are a function of house prices, which are instrumented by property tax variation. Geerolf and Grjebine (op. cit.) find that a 10\% increase in house prices provokes deterioration in the current account balance by $1.7 \%$ of GDP.

${ }^{11}$ We may also note that our theoretical framework assumes implicitly that credit is endogenously determined, i.e. commercial banks provide external finance in response to credit-worthy households' requests (Graziani, 2003; Arestis and Gonzalez, 2014). In view of this assumption there is no room for the adoption of a testable hypothesis that suggests that capital inflows provoke an increase in the money supply that induces a decline in interest rates and makes external finance more affordable.
} 
Nevertheless, the interaction between the current account balance and house prices goes further. Specifically, if the external deficit is maintained or grows through time, an increase in interest rates will be necessary to attract capital inflows to finance the external indebtedness. This implies a negative effect on the demand for housing in view of rising mortgage rates, and subsequently, increasing user cost of dwellings.

In other words, we can suggest that in the short run there are common drivers of house prices and current account deficits, while in the long run a negative effect on house prices emanates from the existence of current account deficits. ${ }^{12}{ }^{13}$ This assumption is justified in view of the fact that financial markets penalise those economies, which are excessively and continuously indebted for a long period. In this context, an interesting issue to be addressed is the existence of different behavioural patterns in the relationship between these two variables, namely, house prices and the current account balance, under different regimes of exchange rates.

Let us assume that house prices and current account balances are driven by common fundamentals, as discussed above. Any deterioration of the current account balance will require an increase in the basic interest rate by the central bank in order to eliminate the current account deficit. Subsequently, rising interest rates will attract capital flows from international investors who are looking for higher returns. This increase in the cost of external finance will feed into higher mortgage rates, which will have a counterbalancing effect on house prices. At the same time, rising capital inflows will provoke the appreciation of the currency. In the case of an open economy with a flexible exchange rate, rising interest rates will affect consumption negatively, while the appreciation of the currency will favour an increase in imports and a decline in exports, which are less competitive in international markets. This will reduce negatively aggregate demand, and subsequently employment and disposable income. In this context, the natural adjustment of the current account balance will curb demand for housing, and subsequently, house prices.

However, in the case of an open economy with a fixed exchange rate, the monetary authority will need to intervene and alter the money supply in order to keep the exchange rate constant. This intervention will accelerate inflation, which deteriorates the competitiveness of the economy under consideration. It will also induce a decline in exports, and subsequently negative effects will emerge on aggregate demand, employment and income. As in the case

\footnotetext{
${ }^{12}$ Another important common driver of both variables is expectations of those who participate in the market. The importance of current expectations on the evolution of prices in the housing market has been extensively discussed, i.e. the so-called 'amplification' effect (Shiller, 2007). Optimistic expectations about house prices can materialise if individuals decide to get into the market to anticipate future hikes in prices. At the same time, it may be the case that home owners go for higher consumption if they expect a revaluation of the assets that they currently own. This higher consumption would have a reflection in terms of the current account balance.

${ }^{13}$ Special attention needs to be drawn to the issue of the direction of the causality between house prices and the dynamics of the current account balance. This issue is explored deeper in the empirical part of this contribution. In doing so, the Granger causality test (Granger, 1969; Sims, 1972) has been employed.
} 
discussed above, a reduction in disposable income will curb the demand for housing. It may also provoke the collapse of the housing market since some borrowers who are unemployed are not able to repay their mortgages and eventually will default. However, a fixed exchange rate system could exacerbate the dynamics of the housing market. Specifically, the inflation, which emerges from the central bank's intervention, will make 'cheaper' real indebtedness. This could create incentives to some households to get into debt and acquire new properties for speculation. This will increase house prices and favours the development of bubbles in the housing market.

After elaborating on the complex relationship between house prices and the current account balance, attention is drawn to the other variables included in our specification. More specifically, home buyers' income has been extensively discussed as a key driver of house prices. An increase in the effective level of income induces a rise in the demand for owneroccupied dwellings. Haurin and Gill (1987) check empirically this hypothesis by means of a sample that collects data on military employees in the United States. Haurin and Gill (op. cit.) suggest that rising uncertainty about the expected level of income in the near future induces a decline in the demand for housing. Moreover, Ballesteros (2002) highlights the importance of income in the explanation of house prices via housing affordability. Ballesteros (op. cit.) provides empirical evidence of this relationship in the case of the Philippines where the lack of cheap and sufficient sources to access external finance reinforces this proposition. Our model does account for this relationship and includes the real disposable income per capita, $Y$, variable in equation (3).

The mortgage rate, $i$, which affects dwelling prices negatively, is also relevant to our house price equation. ${ }^{14,15}$ This suggests that accommodating monetary policy and low interest rates had had a significant effect in the development of the housing bubble, mainly in the US housing market, prior to the 'great recession'. The mortgage rate reflects the evolution of the central bank interest rate, which is the basic instrument used by central banks to control inflation. The lack of homogeneous data on the mortgage rate during the period under investigation for some of the countries included in our sample, forces the use of a proxy for this variable. ${ }^{16}$ Specifically, we approximate the rate of interest of mortgages by the longterm interest rate (AMECO, 2011).

Another important variable is real residential investment, $R^{R I}$. An increase in real residential investment reduces pressure on house prices since it means an increase in the

\footnotetext{
${ }^{14}$ See Yang et al. (1998) for a detailed analysis of interest rates in the context of borrowers' default/ mortgage repayment decisions.

${ }^{15}$ For simplicity reasons, we assume a single interest rate in the credit market, which is relevant for home buyers and property developers.

${ }^{16}$ The European Mortgage Association (2011) provides the representative interest rates on new mortgage loans for a sample of 33 economies. However, the availability of national time series varies substantially across countries. In general terms they do not start before 1990.
} 
supply of dwelling assets, which are available for new home buyers who wish to participate in this market. In our model the volume of credit, $B^{C}$, is considered as a proxy for mortgage lending standards, since the volume of bank credit to the private sector moves procyclically with credit standards (Geanakoplos, 2010). ${ }^{17}$ Credit standards are weakened during the expansionary stage of the business cycle due to the presence of positive expectations and low rates of defaults. As a result the share of borrowers that are considered as solvent, and the volume of credit in the economy, both expand. The huge development of cheap credit in the pre-crisis period, with the extreme example of the US subprime loans, suggests a positive correlation between credit and house price appreciation (Mian and Sufi, 2009; Adelino et al., 2012); ${ }^{18,19}$.However, the impact of this variable cannot be restricted only at the boom of the market, since after the bust liquidity constraints emerge. The tightening of borrowing conditions and the quality of the existing mortgages could accelerate the fall of house prices (Benetrix et al., 2011). ${ }^{20}$ Specifically, there is a feedback between house prices and the volume of credit through the 'collateral' channel, which is a variant of the 'financial accelerator' hypothesis (Bernanke et al., 1998). More specifically, dwelling acquisitions are positively influenced by an easy access to bank credit, which is more likely the higher the value of the assets that are utilised to secure the relevant mortgage. In this context, there is an acceleration of house price appreciation, which is favoured by the existence of cheap and abundant credit. If we explore this relationship the other way round, rising house prices, induce expectations about future house price appreciation and increase the value of the 'collateral', which leads to a relaxation of current credit standards to obtain a mortgage. Moreover, Andrés and Arce (2012) suggest that an increase in the competition among the commercial banks in Europe and the United States before 2007 could have encouraged an excessive household indebtedness. Andrés and Arce (op. cit.) further suggest that high levels of competition could be responsible for increasing financial instability in the short run. This contribution concludes that competition in the banking sector is also important since it could help in the recovery after the bust. Also, and along the same lines, Borio and Lowe (2002) suggest that fast growth of credit enables hikes in house prices that raise the probability of financial instability.

\footnotetext{
${ }^{17}$ It is approximated by the domestic credit to the private sector as percentage of GDP.

${ }^{18}$ Dübel and Rothemund (2011) offer a comparison between the US and EU mortgage credit markets.

${ }^{19}$ Abel and Deitz (2010) suggest that the causation between house prices and nonprime lending activities takes place in both directions: the development of nonprime loans permits an increase in house prices, since this stimulates housing demand. At the same time, a rapid increase in house prices favours risky loans (see also Goetzmann et al., 2009).

${ }^{20}$ Abel and Deitz (2010) examine the development of Upstate New York's housing market and find a stable behaviour of house prices in this area before and after the crisis, essentially due to the reduced volume of subprime mortgages in the area.
} 
These considerations help to explain increases in house prices and boost of the housing cycle. ${ }^{21}$ Moreover, credit standards also have an impact on the supply side, due to the presence of 'small builders' who require external finance in order to start their activities. Under these conditions, a relaxation of the credit conditions and a reduction in the spread that this particular kind of borrowers would have to accept in order to obtain the funds, have a double positive effect. On the one hand, the production cost for housing is lower, and so, housing becomes more affordable. On the other hand, more builders are going to be able to execute their projects. As a result, an increase in the supply of housing emerges. This implies that supply is becoming more elastic and increases in demand have less of an impact on prices. These two considerations induce house prices to decline in the short run, but in the long run falling prices increase the demand for housing.

We may also note that public authorities exert an effect on housing demand by means of levies, subsidies and deductibility of some specific costs, as for example a fraction of the mortgage interest payments. Our proposal is focused on the impact of taxation in order to examine whether a high level of taxes on properties could influence the behaviour of homebuyers in the sense that they prefer renting a property rather than buying it. ${ }^{22}$ Poterba (1992), discusses the importance of the impact of this policy instrument in the context of the United States and Canada. Poterba (1994) also argues that taxation is the most relevant tool to influence the dynamics of the housing market. Our testable hypothesis suggests that an increase in property taxation could modify individuals' preferences, thereby implying that some potential homebuyers would abandon the housing market. This means a slowdown in demand, and reduction in house prices would take place. Specifically, our model proxies taxation by the ratio of tax revenues (from immovable property) over house prices, $\Gamma^{23}$

\section{Empirical Investigation}

\subsection{Preliminary Econometric Techniques}

A preliminary step in our empirical investigation is the determination of the order of integration of the time series included in our sample. More specifically, we apply the

\footnotetext{
${ }^{21}$ See Miller et al. (2011) for further explanations of the 'collateral' channel and the 'wealth' effect related to rising house prices.

22 See Muellbauer and Cameron (1998) as an example of a study of the effects of taxation on the housing market and a discussion of how the taxation system can stabilise the UK housing market.

${ }^{23}$ Hilbers et al. (2008) provide a detailed description of housing-related taxation in Austria, Belgium, Denmark, Finland, France, Germany, Greece, Ireland, Italy, Netherlands, Norway, Portugal, Spain, Switzerland, Sweden, and the United Kingdom. Their analysis shows huge taxation disparities among these countries, which makes it difficult to make comparisons. They approximate the tax burden on housing by means of the ratio of tax revenues to house prices in their attempt to deal with this problem. We also adopt this approach in our empirical analysis.
} 
following unit root tests: (i) the augmented Dickey-Fuller (Dickey and Fuller; 1979, 1981) tests; (ii) the Phillips-Perron (Phillips and Perron, 1988) test; (iii) the GLS-based DickeyFuller (Nelson and Plosser, 1982) test; and (iv) the Lee and Strazicich's (2003) unit root test with two breaks which are endogenously determined. ${ }^{24}$ In addition, a stationary test is also employed, i.e. the Kwiatkowski-Phillips-Schmidt-Shin (Kwiatkowski et al., 1992) test. The results of this set of tests point to the existence of a mixture of $I(1)$ and $I(0)$ time series. Then we proceed to apply the ARDL bounds testing cointegration approach (Pesaran and Shin, 1999; Pesaran et al, 2001). There is strong evidence in favour of the null hypothesis, which suggests the lack of a relationship among the variables in the long run. This compels us to apply an alternative technique. In doing so, we filter our time series by taking first differences of our data.

Moving on to the determination of the order of integration of those differentiated time series, which our sample comprises of, we apply again the same set of unit root tests mentioned above. The results of these tests suggest trend stationarity of the time series under scrutiny. ${ }^{25}$

In order to test econometrically our testable hypothesis, which is captured by equation (3), we adopt an Autoregressive Distributed Lag (ARDL) (Gujarati and Porter, 2010) specification and proceed to estimate the model displayed in equation (4), as per below. This procedure is suitable in view of the stationary behaviour of those time series of our data set. In an ARDL framework lagged level variables are included on the right hand side of the equation and long-run elasticities can be derived from the resulting coefficients. We proceed to regress the following ARDL model: ${ }^{26}$

$$
\mathrm{P}^{H}{ }_{t}=\beta_{0}+\sum_{i=1}^{n} \beta_{i} \mathrm{P}^{H}{ }_{t-i}+\sum_{j=0}^{m} \beta_{j} V_{t-j}+\gamma_{t}
$$

where all the variables have the same meaning as above, with the exemption of $V$, which is a vector that includes real disposable income, $Y$, the volume of private credit, $B^{C}$, real long-run interest rate, $i$, real residential investment, $R^{R I}$, current account balance, $C^{A B}$, and property taxation-to-house price, $\Gamma, \beta_{0}$, which accounts for the intercept and $\gamma$, which is a vector of

\footnotetext{
${ }^{24}$ The use of this test is fundamental to avoid errors in the identification of the order of integration. This is so since the period under consideration is long enough for structural changes to take place potentially.

${ }^{25}$ In order to preserve space in this paper, the results of these unit root/stationarity tests are not reported in the paper. They are, however, available from the authors upon request.

${ }_{26}$ The variables included in the ARDL specification are expressed in either rates of growth, which are approximated by means of the first difference of the series in logarithms, or in absolute differences in those cases where it was not possible to take logarithms of the series in levels, i.e. in the case of real interest rates and current account balances as percentages of GDP.
} 
error white noise process. All the variables are expressed in terms of logarithms except for the mortgage rate and the current account balance. ${ }^{27}$

We proceed to estimate the model proposed in equation (4) by means of the least squares technique with breakpoints (EViews, 2013). The least squares technique with breakpoints (op. cit.) is preferred to other kind of relevant techniques, for example, timevarying parameters VARs (TVP-VAR), since our sample only comprises of annual data for a period of 44 years and time-varying parameter techniques perform better in larger sample sizes. $^{28}$ This technique applies the Bai and Perron (2003) approach to determine structural breaks endogenously. This procedure permits the estimated coefficients to vary across observations, i.e. it provides specific and different estimations for each sub-sample. The utilisation of this technique is convenient since we are dealing with a sufficiently long historical period, where it is likely that our time series present structural breaks. Moreover, we adopt the 'general-to-specific' (Hendry and Richard, 1983) approach so that in the final regressions only those variables that are significant at the $90 \%$ confidence limit are included.

Finally, several diagnostics/statistics are employed to assure the validity of our estimates. More specifically, we utilise: (i) the Breusch-Godfrey Serial Correlation LM (Breusch, 1979; Godfrey, 1978) statistic, which tests for the possibility of autocorrelation in the residuals; (ii) the White (White, 1980) test, with and without cross terms, which checks for the homoscedasticity of the residuals; (iii) the Jarque-Bera (1980) test to check for the normality of the residuals; (iv) the ARCH (Engle, 1988) test, which checks for the lack of ARCH effects; ${ }^{29}$ and (v) the stability of the parameters of our model is tested by means of the CUSUM and the CUSUM of squares tests (Brown et al., 1975). ${ }^{30}$

\subsection{Data}

We proceed to estimate our testable hypothesis in the case of the following 17 economies: Australia, Belgium, Canada, Denmark, Finland, France, Germany, Italy, Ireland, Japan, New Zealand, Norway, the Netherlands, Spain, Sweden, the United Kingdom and the United States. In all the cases, the annual data employed covers the period 1970-2013. This period is long enough to study the 'financialisation' era and the post-August 2007 crisis period. It is important to study the evolution of house prices during these periods since one of the most

\footnotetext{
${ }^{27}$ EViews 8.0 is the econometric package employed to estimate the empirical relationships and conduct those diagnostics/statistics as required.

${ }^{28}$ See, Barnett (2012) for a detail discussion of these techniques, and what is suggested in the text.

${ }^{29}$ The ARCH effect is a white-noise test, which examines whether a non-linear auto-correlation exists.

${ }^{30}$ The results of all these tests are not included in this paper but can be obtained from the authors upon request. In all the cases, the CUSUM and the CUSUM of squares tests confirm the stability of the parameters of our estimates.
} 
relevant features of a financialised economy is the existence of asset bubbles. In view of this it is possible to assume that 'bubble' episodes are more frequent under the regime that emanated from the financial liberalisation process, which started in the United States in the mid-1970s.

Our sample gathers data from different sources. First of all, our annual time series for house prices are produced by annualising quarterly data, published by the Federal Reserve Bank of Dallas. Due to the fact that this data series starts in 1975, we extend our annual time series back to 1970 by computing other information published by the Organisation for Economic Co-operation and Development (OECD) and the Bank for International Settlements (BIS). ${ }^{31}$

Another important data source is the AMECO databank where the following relevant time series are available: (a) Gross National Disposable Income per head of population; (b) Gross Fixed Capital Formation by type of goods at current prices (dwelling); (c) Balance on Current Transactions with the rest of the world; (e) Real Long-term Interest rate; and d) Gross Domestic Product Price Deflator. ${ }^{32}$

We may also note that the OECD provides the data on taxation over immovable property, which is needed to calculate the taxation over property-to-house prices ratio. ${ }^{33}$ In addition to that, the World Bank database is utilised to obtain annual time series on credit to private sector (\% GDP) for the period $1970-2013 .^{34}$

\section{Empirical Results}

\subsection{Addressing the issue of unravelling causality}

Our theoretical hypothesis has suggested a potential relationship between house prices and the current account balance; we thereby proceed to explore the direction of causality between these two variables by means of the Granger causality test (Granger, 1969; Sims, 1972). ${ }^{35,36}$ This test is needed to provide additional support to our theoretical framework and a better

\footnotetext{
${ }^{31}$ The information published by these three data providers is available at: http://www.dallasfed.org/institute/houseprice/; http://www.bis.org/; http://stats.oecd.org/index.aspx

32 This annual data can be obtained from: http://ec.europa.eu/economy finance/ameco/user/serie/SelectSerie.cfm

${ }^{33}$ The OECD Revenue Statistics are available at: http://stats.oecd.org/ The last data of these statistics corresponds to 2011/12 depending on the country under consideration. In order to extend the relevant time series to 2013, we extrapolate the data by using the rate of growth of the last period available.

34 This information is available at:

http://databank.worldbank.org/data/views/variableselection/selectvariables.aspx?source=world-developmentindicators

${ }^{35}$ This test has been conducted by means of EViews.

${ }^{36}$ In terms of the Granger causality test, causality refers to the chronological order of movements in the time series under consideration (Brooks, 2008).
} 
understanding of the relationship between the relevant variables. The results of these tests are shown in Table 1.

TABLE 1: GRANGER CAUSALITY TEST

\begin{tabular}{|c|c|c|c|c|}
\hline \multicolumn{5}{|c|}{ Granger causality test } \\
\hline & Null hypothesis & No. Observations & F-Statistic & Prob. \\
\hline \multirow[t]{2}{*}{ Australia } & House prices does not Granger cause Current account balance & 42 & 0.5444 & 0.5847 \\
\hline & Current account balance does not Granger cause House prices & 42 & 1.5548 & 0.2247 \\
\hline \multirow[t]{2}{*}{ Belgium } & House prices does not Granger cause Current account balance & 42 & 4.5726 & 0.0168 \\
\hline & Current account balance does not Granger cause House prices & 42 & 3.6797 & 0.0349 \\
\hline \multirow[t]{2}{*}{ Canada } & House prices does not Granger cause Current account balance & 42 & 0.3821 & 0.6850 \\
\hline & Current account balance does not Granger cause House prices & 42 & 1.0511 & 0.3597 \\
\hline \multirow[t]{2}{*}{ Denmark } & House prices does not Granger cause Current account balance & 42 & 6.6823 & 0.0033 \\
\hline & Current account balance does not Granger cause House prices & 42 & 2.6519 & 0.0839 \\
\hline \multirow[t]{2}{*}{ Finland } & House prices does not Granger cause Current account balance & 42 & 1.682 & 0.1999 \\
\hline & Current account balance does not Granger cause House prices & 42 & 4.3362 & 0.0203 \\
\hline \multirow[t]{2}{*}{ France } & House prices does not Granger cause Current account balance & 42 & 1.9772 & 0.1528 \\
\hline & Current account balance does not Granger cause House prices & 42 & 3.6444 & 0.0359 \\
\hline \multirow[t]{2}{*}{ Germany } & House prices does not Granger cause Current account balance & 42 & 2.6913 & 0.0810 \\
\hline & Current account balance does not Granger cause House prices & 42 & 0.9665 & 0.3898 \\
\hline \multirow[t]{2}{*}{ Ireland } & House prices does not Granger cause Current account balance & 42 & 5.9224 & 0.0059 \\
\hline & Current account balance does not Granger cause House prices & 42 & 4.8183 & 0.0138 \\
\hline \multirow[t]{2}{*}{ Italy } & House prices does not Granger cause Current account balance & 42 & 0.0385 & 0.9622 \\
\hline & Current account balance does not Granger cause House prices & 42 & 8.1431 & 0.0012 \\
\hline \multirow[t]{2}{*}{ Japan } & House prices does not Granger cause Current account balance & 42 & 2.9443 & 0.0651 \\
\hline & Current account balance does not Granger cause House prices & 42 & 1.844 & 0.1724 \\
\hline \multirow[t]{2}{*}{ Netherlands } & House prices does not Granger cause Current account balance & 42 & 2.6089 & 0.0871 \\
\hline & Current account balance does not Granger cause House prices & 42 & 5.5057 & 0.0081 \\
\hline \multirow[t]{2}{*}{ New Zealand } & House prices does not Granger cause Current account balance & 42 & 4.3953 & 0.0194 \\
\hline & Current account balance does not Granger cause House prices & 42 & 11.6578 & 0.0001 \\
\hline \multirow[t]{2}{*}{ Norway } & House prices does not Granger cause Current account balance & 42 & 1.4021 & 0.2588 \\
\hline & Current account balance does not Granger cause House prices & 42 & 7.0439 & 0.0026 \\
\hline \multirow[t]{2}{*}{ Spain } & House prices does not Granger cause Current account balance & 42 & 2.1067 & 0.1360 \\
\hline & Current account balance does not Granger cause House prices & 42 & 4.2219 & 0.0223 \\
\hline \multirow[t]{2}{*}{ Sweden } & House prices does not Granger cause Current account balance & 42 & 2.0459 & 0.1436 \\
\hline & Current account balance does not Granger cause House prices & 42 & 6.3143 & 0.0044 \\
\hline \multirow[t]{2}{*}{ UK } & House prices does not Granger cause Current account balance & 42 & 3.7853 & 0.0319 \\
\hline & Current account balance does not Granger cause House prices & 42 & 2.9948 & 0.0623 \\
\hline \multirow[t]{2}{*}{ US } & House prices does not Granger cause Current account balance & 42 & 2.1689 & 0.1286 \\
\hline & Current account balance does not Granger cause House prices & 42 & 0.7055 & 0.5004 \\
\hline
\end{tabular}

These results permit us to identify four different patterns: a) house prices and current account balances are independent; b) house prices cause current account balances; c) current account balances cause house prices; and d) there is a feedback between house prices and current account prices. 
More specifically, current account balances and house prices are independent in the case of Australia, Canada and the United States. On the contrary our results identify a bidirectional feedback at the $5 \%$ significance level between house prices and the current account balances in the case of Belgium, Ireland and New Zealand. Moreover, the same conclusion can be drawn in the case of Denmark, the United Kingdom and the Netherlands when a $10 \%$ significance level is considered.

In addition to that, we can emphasise the existence of a unidirectional causality from the current account balance to house prices in the case of the following economies: Finland, France, Italy, Norway, Spain and Sweden. This empirical evidence supports the idea that the current account balance and house prices are driven by common determinants.

Apart from that, our results also point to the fact that lags of house prices should be significant explanatory variables for the current account balances in the case of Germany and Japan. However, the study of the unidirectional causality, which runs in that direction, goes beyond the scope of this paper since we are not estimating a model that explains the evolution of current account imbalances as a function of house prices.

\subsection{Main Results}

The results obtained by applying the methodology described in Section 3.1 are presented in Table 2. To begin with the discussion of our econometric results, we highlight that the least squares technique with breakpoints (EViews, 2013) does not identify structural breaks in the case of Australia, Canada, Denmark, France, Finland, Ireland, New Zealand, Norway and the United States. Two different sub-periods are found in the case of Belgium, Germany, Japan, Spain, Sweden, and the United Kingdom. Estimations for three different sub-periods are produced in the case of Italy and the Netherlands. The precise dates, which correspond to the particular period that the model has been estimated for, are shown in the second column of Table 2.

TABLE 2: House PRICE Estimations (1970-2013)

\begin{tabular}{|c|c|c|c|c|c|c|c|c|c|c|}
\hline \multicolumn{11}{|c|}{ Dependent Variable } \\
\hline & Period & $\begin{array}{c}\text { No. } \\
\text { Observations }\end{array}$ & Constant & $\begin{array}{c}\text { Real disposable } \\
\text { income } \\
\left(\Delta \mathrm{L}_{-} \mathrm{Y}\right)\end{array}$ & $\begin{array}{l}\text { Real residential } \\
\text { investment } \\
\left(\Delta \mathrm{L} \_\mathrm{R}^{\mathrm{RI}}\right)\end{array}$ & $\begin{array}{l}\text { Bank credit } \\
\left(\Delta \mathrm{L} \_\mathrm{B}^{\mathrm{C}}\right)\end{array}$ & $\begin{array}{c}\text { Taxation } \\
\text { property/house prices } \\
\left(\Delta \mathrm{L}_{-} \Gamma\right)\end{array}$ & $\begin{array}{c}\text { Mortgage rate } \\
(\Delta \mathrm{i})\end{array}$ & $\begin{array}{c}\text { Current account } \\
\text { balance } \\
\left(\Delta \mathrm{C}^{\mathrm{AB}}\right)\end{array}$ & $\begin{array}{l}\text { House prices } \\
\left(\Delta \mathrm{L}_{-} \mathrm{P}^{\mathrm{H}}\right)\end{array}$ \\
\hline \multirow[t]{2}{*}{ Australia } & 1973-2013 & 41 & $0.0183^{*}$ & & & $0.2831^{* *}(0)$ & & $-0.2165 * * *(0)$ & & $0.4615^{* * *}(1)$ \\
\hline & & & & & & & & & & $-0.3681 * * * *(2)$ \\
\hline \multirow[t]{2}{*}{ Belgium } & 1973-1982 & 10 & $-0.0890^{* * *}$ & $2.1222^{* * *}(0)$ & $0.4463^{* * *}(2)$ & $1.0500^{* * * *}(0)$ & & & & $0.2870^{*}(1)$ \\
\hline & 1983-2013 & 31 & 0.0107 & 0.3544 & $0.0870(2)$ & 0.0464 & & & & $0.4033^{* *}(1)$ \\
\hline Canada & 1973-2013 & 41 & 0.0017 & $0.6246^{* *}(0)$ & & & & $-0.8985^{*}(0)$ & $-1.8449 * *(0)$ & $0.4397^{* * *}(1)$ \\
\hline Denmark & $1972-2013$ & 42 & $-0.0223^{* *}$ & $2.0486^{* * * *}(0)$ & & & & $-1.6104 * * *(0)$ & & $0.3276^{* * * *}(1)$ \\
\hline Finland & $1972-2013$ & 42 & -0.0121 & $0.9677^{* * * *}(0)$ & & & & & & $0.4799 * * *(1)$ \\
\hline
\end{tabular}




\begin{tabular}{|c|c|c|c|c|c|c|c|c|c|c|}
\hline France & 1973-2013 & 41 & 0.0001 & $1.0633 * * *(0)$ & & & & & & $0.6890 * * *(1)$ \\
\hline & & & & $-0.5810^{* *}(2)$ & & & & & & \\
\hline \multirow[t]{4}{*}{ Germany } & 1973-1981 & 9 & $0.0273^{* * * *}$ & & $0.1244 * *(0)$ & & $-0.2407 * *(0)$ & & & $0.0630(1)$ \\
\hline & & & & & & & & & & $-0.6828 * * * *(2)$ \\
\hline & 1982-2013 & 32 & 0.0000 & & $0.0881 * *(0)$ & & $-0.1854 *(0)$ & & & $0.4737^{* * *}(1)$ \\
\hline & & & & & & & & & & $-0.1550(2)$ \\
\hline Ireland & $1972-2013$ & 42 & -0.0125 & $1.0048^{* * *}(0)$ & & & & & $-0.4852 *(0)$ & $0.4796 * * *(1)$ \\
\hline \multirow[t]{3}{*}{ Italy } & 1972-1978 & 7 & -0.0305 & $-0.1484(1)$ & & & & $-5.5969 * * *(1)$ & & $0.4801 * * *(1)$ \\
\hline & 1979-1990 & 12 & -0.0030 & $1.8538 * *(1)$ & & & & $-3.9428 * * *(1)$ & & $0.9872 * * *(1)$ \\
\hline & 1991-2013 & 23 & -0.0094 & $0.3476(1)$ & & & & $-0.4289(1)$ & & $0.6656 * * *(1)$ \\
\hline \multirow[t]{2}{*}{ Japan } & 1972-1977 & 6 & $-0.0869 * * *$ & $1.8069 * *(0)$ & & $0.9536 * *(1)$ & & & & $0.4807^{* * * *}(1)$ \\
\hline & $1978-2013$ & 36 & -0.0073 & $0.3513(0)$ & & $0.4551(1)$ & & & & $0.6599 * * *(1)$ \\
\hline \multirow[t]{3}{*}{ Netherlands } & 1972-1977 & 6 & 0.0707 & $-2.1575(0)$ & & & $-0.4193 * * *(1)$ & & & $1.4546 * * *(1)$ \\
\hline & 1978-1983 & 6 & $-0.0841 * * *$ & $3.5911 * * *(0)$ & & & $-0.0863(1)$ & & & $0.0940(1)$ \\
\hline & $1984-2013$ & 30 & -0.0104 & $0.7030 * *(0)$ & & & $0.0945(1)$ & & & $0.8705^{* * * *}(1)$ \\
\hline New Zealand & $1972-2013$ & 42 & -0.0014 & $0.9384 * *(0)$ & & & & $-0.1282 *(0)$ & $-0.8656 * * *(0)$ & $0.5239 * * *(1)$ \\
\hline Norway & $1972-2013$ & 42 & -0.0035 & $0.6027 *(0)$ & & $0.2974 * *(0)$ & $-0.1598 * * *(0)$ & & & $0.3710^{* * * *}(1)$ \\
\hline \multirow[t]{4}{*}{ Spain } & 1973-1981 & 9 & -0.0125 & $1.8102 * * *(0)$ & & & & & & $0.1325(1)$ \\
\hline & & & & & & & & & & $-0.5300 * *(2)$ \\
\hline & $1982-2013$ & 32 & -0.0081 & $0.8776 * *(0)$ & & & & & & $0.9837^{* * * *}(1)$ \\
\hline & & & & & & & & & & $-0.2759(2)$ \\
\hline \multirow[t]{2}{*}{ Sweden } & $1972-1992$ & 21 & $-0.0222 * *$ & $0.8933 *(1)$ & $0.2820 * *(0)$ & & & $-0.1674(1)$ & & $0.5187^{* * * *}(1)$ \\
\hline & 1993-2013 & 21 & $0.0294 * * *$ & $-0.3249(1)$ & $0.1383 *(0)$ & & & $-1.7845 * * *$ (1) & & $0.2489(1)$ \\
\hline \multirow[t]{2}{*}{ UK } & 1972-1978 & 7 & $-0.0579^{* *}$ & $3.4582 * *(0)$ & & & & & $-3.2047(0)$ & $-0.0667(1)$ \\
\hline & 1979-2013 & 35 & -0.0144 & $1.4580 * *(0)$ & & & & & $-2.8607 * * *(0)$ & $0.5282 * * *(1)$ \\
\hline US & $1972-2013$ & 42 & $-0.0101 * *$ & $0.6325 * * *(0)$ & & $0.1815 * *(0)$ & & & & $0.5772 * * *(1)$ \\
\hline
\end{tabular}

Note: $* * *$ and $* * *$ indicate statistical significance and rejection of the null at the 10,5 and 1 percent significance levels, respectively. Numbers in parentheses, in the case of the variables, show the lag(s) of the relevant variable. $\Delta$ denotes the first difference of each variable. L indicates the logarithm of the corresponding time series.

All the estimated models include an intercept, which is significant in the cases of Australia, Belgium (1973-82), Denmark, Germany (1973-81), Japan (1972-77), the Netherlands (1978-83), Sweden, the United Kingdom (1972-78), and the United States.

Focusing our attention on the impact of lagged terms of house prices, there is ample evidence that house prices in the recent past are an explanatory element of the current price of dwellings. This evidence is easily understood in view of the fact that an important element, which drives potential home buyers to enter into the housing market, is the evolution of expectations. The significance of these lagged terms is consistent with the notion of 'adaptive expectations' and provides further support to the behavioural pattern described in Shiller (2007). Shiller (op. cit) points to the fact that during boom periods home buyers' decisions rely heavily on the recent developments of this market. In this context, we can expect that home buyers revise their expectations about future house prices by taking into account the evolution of house prices in the last one or two periods. More specifically, house prices lagged by 1 and 2 periods are significant in the case of Australia where elasticities of 0.46 
and -0.36 percent have been estimated over the period 1973-2013. A similar pattern has also been found in Germany where the estimated elasticities are $0.06 \%$ and $-0.68 \%$, for the first period; and 0.47 and -0.15 for the period commencing in 1982. The same phenomenon is also identified in the case of Spain, where the elasticities vary from $0.13 \%$ to $0.98 \%$ for the first lag and -0.53 and -0.27 for house prices in $t-2$. Moreover, house prices in $t-1$ are also significant in the rest of the markets under consideration. The highest impact of this variable is found in the case of Netherlands, where $1 \%$ increase of house prices in the previous period leads to a $1.45 \%$ increase in actual house prices over the period 1972-78; although it provokes lower increases after $1978(0.87 \%)$. A remarkable effect of the momentum of the housing market in the evolution of house prices is also found in Italy, where a $1 \%$ increase of lagged house prices were responsible for $0.98 \%$ house price appreciation during 1979-90. On the other hand, the lowest elasticities of lagged house prices are identified in the Netherlands $(0.09 \%)$ and Spain $(0.13 \%)$ in the 1970 s.

In terms of the independent variables, and most importantly for the purposes of this contribution, our empirical results identify a negative relationship between current account imbalances and house prices. In terms of our analysis, this negative relationship suggests that an increase in the current account deficit is correlated positively with rising house prices in view of common drivers of current account balances and house prices, as shown in our theoretical hypothesis. More specifically, four markets provide evidence of that relationship between house prices and the deterioration of the current account balance. The strongest impacts are estimated for the UK where our results show a semi-elasticity of $-3.20 \%$ for the first sub-period 1970-1978; while a -2.86 semi-elasticity is estimated since 1979. A strong relationship between both variables is also found in Canada where a $-1.84 \%$ semi-elasticity has been found for the period under consideration. ${ }^{37}$ On the other hand, the lowest appears in Ireland (-0.48) over the period 1972-2013. A slightly higher semi-elasticity is found in New Zealand (-0.86) since 1972. ${ }^{38}$ An interesting feature of the impact of this variable is that its role is maintained through the whole period, which emphasises its importance.

Our results also point to an important role for the real disposable income variable in the determination of house prices in the vast majority of the countries, with the exception of Australia and Germany. The strongest estimated effects are in the case of the Netherlands (3.59) over the period 1978-1983, the United Kingdom (3.45) from 1972 to 1978, Belgium

\footnotetext{
${ }^{37}$ Further investigation of the relationship discussed in the text in the case of Canada is worth undertaking, since the Granger causality test suggested that both variables are independent. This could be undertaken in future research.

${ }^{38}$ The lack of impact of current account balances in those countries where there is a negative influence of mortgage rates on house prices could be an indication that external deficits that are maintained through time provoke rising interest rates, which affect negatively the demand for housing. Further research is needed to confirm this hypothesis and understand better the complexity of this mechanism. This is so since our empirical findings suggest that current account imbalances and mortgage rates are determinants of house prices in countries like Canada and New Zealand.
} 
(1973-1982, 2.12), and Denmark (2.04) since $1972 .{ }^{39}$ Lower elasticities are found in Canada and Norway $(0.62 \%$ and $0.60 \%$ respectively). The weakest impact of disposable income on house prices is evident in the case of Japan (0.35), and Italy (0.34) over the period 1978-2013 and 1991-2013 respectively

Moreover, a positive impact of real residential investment is found in three countries. ${ }^{40}$ Those countries where there is a positive relationship between house prices and residential investment are Belgium, where the relevant elasticity falls from 0.44 to 0.08 since 1983; Germany where a $1 \%$ increase in income induces $0.12 \%$ and $0.08 \%$ increases in house prices in each sub-period; and Sweden where a $0.28 \%$ and $0.13 \%$ elasticities are found for the periods 1973-92 and 1993-2013 respectively.

In terms of the impact of financial elements on house prices, our results point out a positive and important effect that emanates from a relaxation of the credit standards. This means an increase in the volume of credit, which is provided to acquire housing assets. The markets where the elasticity of house prices with respect to the volume of credit is stronger are Belgium and Japan where the estimated elasticity's are $1.05 \%, 0.95 \%$ and $0.45 \%$ over the periods 1973-82, 1972-77 and 1978-2013 respectively. On the contrary, weaker elasticities appear in the case of Norway (0.29), Australia (0.28), and the United States (0.18). In the case of these three countries the estimated impact stays constant throughout the period under consideration.

Regarding the other financial element that is included in our model, namely the mortgage rate, our empirical estimates point to a negative impact of the mortgage rate on house prices, as suggested by our theoretical framework. The strongest role of this variable is observed in the case of Italy, where a $-5.59 \%$ and $-3.94 \%$ semi-elasticities are found over the periods 1972-1978 and 1979-1990 respectively. Moreover, a significant impact of the mortgage rate is also found in Sweden since 1993 and Denmark (-1.78 and -1.61 for the periods 1993-2013 and 1972-2013 respectively). ${ }^{41,}{ }^{42}$ On the other hand, lower semielasticities are found in New Zealand and also in Sweden in the first identified sub-period ($0.12 \%$ and $-0.18 \%$ respectively).

\footnotetext{
${ }^{39}$ The positive effect of income on house price appreciation found in the case of the United Kingdom is along the lines of the result of Barot and Yang (2002). Moreover, our empirical findings in the case of the United States support the results presented in Arestis and Karakitsos (2007).

${ }^{40}$ As advanced in our theoretical framework, the sign of the impact of real residential investment on house prices varies through time. There is a positive relationship in the short run, although it turns into a negative one in the long run. In view of the lack of co-movement between these variables in the long run, i.e. there is no cointegrating relationship between them, we can only expect a positive sign of this coefficient.

${ }^{41}$ IMF (2004) points to a strong negative effect on house prices that emerges from interest rates in the United States economy. This contribution also highlights this effect in the Netherlands and Ireland. However, our empirical analysis does not find the impact of mortgage rates significant in these three economies.

${ }^{42}$ Barot and Yang's (2002) results also point to a negative effect of the mortgage rate on house prices in the case of Sweden.
} 
In addition to that, we find empirical evidence in favour of our other testable hypothesis, which points to taxation over immovable property as an appropriate instrument to curb house price appreciation. More specifically, this negative effect is significant in Germany, where the elasticity varies from $-0.24 \%$ to $-0.18 \%$ since 1982 , and Norway $(-0.15)$. In the case of the Netherlands, the estimated elasticity is twice $(-0.41)$ the one found in the German economy over the same period (1972-77).

All the empirical results presented and discussed in this section have been validated by means of several diagnostic/statistics which are shown in Table 3 in the Appendix of this contribution. In all the cases, the residuals of the relevant regression are non-correlated, homoscedastic and normally-distributed.

\section{Further Comments on the Empirical Findings}

Our empirical findings support our testable hypothesis that highlights the existence of common drivers of house prices and current account deficits, i.e. the existence of a strong aggregate demand effect. We may also note that in the case of those countries, which belong to the Euro Area, we use dummy variables to separate the evolution of current accounts in two different periods; i.e. before and after joining the European Exchange Rate Mechanism (ERM). The rationale for this is to deepen the impact of the effects that emanate from the implementation of a fixed exchange rate in the house prices-current account balance 'loop'.

The lack of impact of the current account balance in the case of the Euro Area countries can be explained by the argument that this effect is absorbed partially by the one that emanates from the interest rate. In other words, since there is a single interest rate for these countries, then the mechanism through which a country that has been running current account deficits through time would be forced to face rising interest rates. But this mechanism cannot operate since there is not necessarily a possible adjustment in each single Euro Area country's interest rate.

Elaborating further on our empirical findings, we highlight the importance of house prices in the recent past. As shown above, the momentum of the housing market is captured by the inclusion of past annual house price appreciations. ${ }^{43}$

In terms of the impact of home buyers' disposable income, our empirical findings confirm the importance of housing affordability as an important determinant. Disposable income should be fully taken into account by commercial banks as an important element to

\footnotetext{
${ }^{43}$ Shiller (2007) suggests that the momentum in the housing market is driven by factors such as speculative psychology, optimism and home buyers' overconfidence, namely, social epidemic of optimism. Regarding home buyers' overconfidence, previous contributions (Bloomfield et al. 1999; Gervais and Odean, 2001; Beracha and Skiba, 2011) conclude that those individuals who are not experts and have been taking part in the housing market for short periods tend to be more overconfident.
} 
identify those potential borrowers that are eligible to get into debt without compromising financial stability.

Another important determinant of house price appreciation is investment in real residential assets, as described in the theoretical section of this contribution. As expected, the demand for housing materialises into investment in real estate assets, which means an increase in their prices since supply of housing is fixed in the short run. So this is really a short-term outcome.

Our study also confirms that monetary policy is an important tool to control house prices through two channels: credit and the mortgage rate. The interest rate on housing loans, whose impact in the Italian economy is remarkable, slows down the evolution of house prices since the user's cost increases as a result and housing assets become less affordable. Our findings in the case of this variable, and also the important effect of the volume of credit are consistent with our testable hypothesis. They point out the important mechanisms, which are available for monetary authorities to intervene in this market. An appropriate valuation of the risk associated with lending operations, along with better regulation in terms of prudential policies, are required.

Furthermore, our research draws attention to the 'channels' through which the public sector authorities could act on the housing market to slow down house price appreciation. First, the impact of fiscal policy cannot be ignored since taxation over property exerts a negative effect on house prices due to the fact that it can modify the behaviour of households, thereby reducing the demand for housing. Second, the public sector can influence real disposable income through changes in taxation and public expenditure. In addition to that, previous empirical contributions (Geerolf and Grejbine, 2013) suggest that unexpected increases in property taxes exert an immediate impact on house prices because of capitalisation. This conclusion is along the lines of our empirical findings in the case of Germany, the Netherlands and Norway.

The discussion above is very relevant in the context where several episodes of sharp house price movements related to financial instability problems have occurred since 1990, as for example, in Sweden, Ireland, Spain, the United Kingdom and the United States. The IMF (2011) study argues that upward and downward movements in housing prices are stronger in those economies where the government is more involved in real estate finance. At the same time, these economies also display a rapid credit growth; Reinhart and Rogoff (2009) provide empirical evidence of relevant banking crises related to housing bubbles. 


\section{Summary and Conclusions}

This contribution focuses on the role played by the external sector on the evolution of house prices. As advanced in our theoretical framework, house prices and current account deficits are positively related. This is so since house prices and current account imbalances are driven by common fundamentals. This provides an explanation for the fact that some of the economies whose housing markets have collapsed exhibit current account imbalances as well. This relationship can be reinforced in those cases where an active construction sector requires a great deal of imports of raw materials; for example, iron, cooper, aluminium, etc, as necessary and relevant inputs. Our contribution also attempts to examine the extent to which fiscal and monetary authorities could avoid the creation of real estate bubbles.

In terms of economic policies, fiscal policy, which can be considered as a more useful instrument than regulation of the supply of housing, should be used more intensively. For instance, new taxes should be introduced in this market to control those transactions, which involve the same property and take place in a short time period, since its aim is merely speculative. Regarding monetary policy, manipulation of interest rates in order to curb the demand for housing is an important tool that monetary regulators should utilise since the financial sector has to provide the financial resources, which are required to permit the normal functioning of the real economy. However, they should play a much more important role in terms of prudential policy in order to constrain the potential demand for mortgages just to those participants that are solvent. This increase in regulation also has to affect credit conditions; for example, the amount of equity withdrawal should not be close to $100 \%$ of the value estimated for the relevant asset in a 'healthy' banking system. To make the point the implementation in the United Kingdom of those mortgage controls, which have come into force in October 2014 (Financial Times, 2014) are important. It is paramount to keep debt-toincome ratios within reasonable limits in order to avoid the so-called 'problem debt', whose associated annual cost in the case of the United Kingdom has been estimated to be $£ 8.3 \mathrm{bn}$ (BBC, 2014).

Another line of reforms would have to be based on the lessons learnt from the past; for example, the effects of the Japanese 'third generation mortgages', which suggest a reduction in the maturity of mortgages. Finally, monetary policy should also account for house prices in its design. More specifically, central banks should monitor house prices closely and take into account house price appreciation when establishing their inflation targets. This is paramount since in the context of rising house prices, home owners will go for higher consumption in view of the 'wealth' effect. Then it would be difficult to 'anchor' households' expectations if an important element upon which they base their behaviour is ignored. 


\section{References}

Abel, J.R. and Deitz, R. 2010. Bypassing the Bust: The Stability of Upstate New York's Housing Markets during the Recession. Federal Reserve Bank of New York Current Issues in Economics and Finance 16: 1-9.

Adam, K., Kuang, P., and Marcet, A. 2011. House Price Booms and the Current Account. NBER Working Paper no. 17224, National Bureau of Economic Research, Cambridge MA.

Adelino, M., Schoar, A., and Severino, F. 2012. Credit Supply and House Prices: Evidence from Mortgage Market Segmentation. NBER Working Paper no. 17832, National Bureau of Economic Research, Cambridge MA.

Aizenman, J. and Jinjarak, Y. 2009. Current Account Patterns and National Real Estate Markets. Journal of Urban Economics 66: 75-89.

AMECO 2011. AMECO Databank List of Variables. Available at: http://ec.europa.eu/economy-finance/db-indicators/ameco/index-en.htm

Andrés, J. and Arce, O. 2012. Banking Competition, Housing Prices and Macroeconomic Stability. The Economic Journal 122: 1346-72.

Arestis, P. and Karakitsos, E. 2007. Modelling the U.S. Housing Market. Ekonomia 10: 6788.

Arestis, P. and González, A.R. 2014. Bank Credit and the Housing Market in OECD Countries. Journal of Post Keynesian Economics 36: 467-90.

Ballesteros, M.M. 2002. The Dynamics of Housing Demand in the Philippines: Income and Lifecycle Effects. Research Paper Series No. 2002-01, Philippine Institute for Development Studies, Makati City.

Barnett, A., Mumtaz, H., and Theodoridis, K. 2012. Forecasting UK GDP Growth, Inflation and Interest Rates under Structural Change: A Comparison of Models with Time-Varying Parameters. Working Paper no. 450, Bank of England, London.

Barot, B. and Yang, Z. 2002. House Prices and Housing Investment in Sweden and the UK: Econometric Analysis for the Period 1970-1998. Review of Urban and Regional Development Studies 14: 189-216.

BBC 2013. China's Slowdown and the Global Glut, 30 July.

BBC 2014. Problem Debt Costs the UK Economy £8.3bn, Charity Warns, 8 October.

Benetrix, A.S., Eichengreen, B., and O’Rourke, K.H. 2011. How Housing Slumps End. Discussion Paper Series no. 577, University of Oxford, Department of Economics, Oxford.

Benito, A., Thompson, J., Waldron, M,. and Wood, R. 2006. House Prices and Consumer Spending. Quarterly Bulletin, Summer, Bank of England, London.

Beracha, E. and Skiba, H. 2011. Momentum in Residential Real Estate. Journal of Real Estate Finance and Economics 43: 299-320. 
Bernanke, B.S., Gertler, M., and Gilchrist, S. 1998. The Financial Accelerator in a Quantitative Business Cycle Framework. NBER Working Paper no. 6455, National Bureau of Economic Research, Cambridge MA.

BIS 2013. UK Construction: An Economic Analysis of the Sector. Available at: https://www.gov.uk/government/uploads/system/uploads/attachment-data/file/210060/bis-13958-uk-construction-an-economic-analysis-of-sector.pdf

Bloomfield, R.J., Libby, R., and Nelson, M.W. 1999. Confidence and the Welfare of Lessinformed Investors. Accounting, Organizations and Society 24: 623-47.

Borio, C. and Lowe, P. 2002. Asset Prices, Financial and Monetary Stability: Exploring the Nexus. BIS Working Paper no. 114, Bank for International Settlements, Basel.

Breusch, T.S. 1979. Testing for Autocorrelation in Dynamic Linear Models. Australian Economic Papers 17: 334-55.

Cesa-Bianchi, A. 2012. Housing Cycles and Macroeconomic Fluctuations: A Global Perspective. IDB Working Paper Series no. IDB-WP-343, Inter-American Development Bank, Washington, DC.

Dübel, H. and Rothemund, M. 2011. A New Mortgage Credit Regime for Europe. Setting the Right Priorities. CEPS Special Report, Centre for European Policy Studies, Brussels.

Dickey, D. A. and Fuller, W.A. 1979. Distribution of the Estimator for Autoregressive Time Series with a Unit Root. Journal of the American Statistical Association 74: 427-431.

Dickey, D.A. and Fuller, W.A. 1981. Likelihood Ratio Statistics for Autoregresssive Time Series with a Unit Root. Econometrica 49: 1057-72.

Engle, R. 1988. Autoregressive Conditional Heteroscedasticity with Estimates of the Variance of United Kingdom Inflation. Econometrica 96: 893-920.

European Mortgage Federation 2011. Representative Interest Rates on New Mortgage Loans. Hypostat 2010, Brussels.

EViews 2013. EViews 8. User Guide II. IHS Global Inc., Irvine.

Favilukis, J., Kohn, D., Ludvigson, S.C., and Van Nieuwerburgh, S. 2012. International Capital Flows and House Prices: Theory and Evidence. NBER Working Paper no. 17751, National Bureau of Economic Research, Cambridge MA.

Ferrero, A. 2011. House Prices Booms and Current Account Deficits. Unpublished paper, Federal Reserve Bank of New York, New York.

Fraser, P., Hoesli, M., and McAlevey, L. 2012. House Prices, Disposable Income, and Permanent and Temporary Shocks: The N.Z., U.K. and U.S. Experience. Journal of European Real Estate Research 5: 5-28.

Financial Times 2014. Bank of England Limits Mortgages to Protect Recovery. 26 June.

Geanakoplos, J. 2010 Solving the Present Crisis and Managing the Leverage Cycle. Federal Reserve Bank of New York Economic Policy Review, August, 101-31. 
Geerolf, F. and Grjebine, T. 2013. House Prices Drive Current Accounts: Evidence from Property Tax Variation. CEPREMAP Working Paper no. 1315, Centre Pour la Recherche Economique et Ses Applications, Paris.

Gete, P. 2010. Housing Markets and Current Account Dynamics. Mimeo, Georgetown University.

Gervais, S. and Odean, T. 2001. Learning to Be Overconfident. Review of Financial Studies 14: $1-27$.

Godfrey, L.G. 1978. Testing against General Autoregressive and Moving Average Error Models when the Regressors Include Lagged Dependent Variables. Econometrica 46: 1293302.

Goetzmann, W.N. Peng, L., and Yen, J. 2009. The Subprime Crisis and House Price Appreciation. NBER Working Paper no. 15334, National Bureau of Economic Research, Cambridge MA.

Granger, C.W.J. (1969), "Investigating Causal Relations by Econometric Methods and CrossSpectral Methods", Econometrica, 34: 424-438.

Graziani, A. 2003. The Monetary Theory of Production. Cambridge: Cambridge University Press.

Gujarati, D.N. and Porter, D.C. 2010. Econometría Básica. McGraw-Hill Interamericana, Bogotá.

Haurin, D.R. and Gill, H.L. 1987. Effects of Income Variability on the Demand for Owneroccupied Housing. Journal of Urban Economics 22: 136-50.

Haughwout, A., Peach, R.W., Sporn, J., and Tracy, J. 2012. The Supply Side of the Housing Hoom and Bust of the 2000s. Staff Report no. 556, Federal Reserve Bank of New York, New York.

Hendry, D. and Richard, J. 1983. The Econometric Analysis of Economic Time Series. International Statistics Review 51: 3-33.

Hilbers, P., Hoffmaister, A.W., Banerji, A., and Shi, H. 2008. House Prices Developments in Europe: A comparison. IMF Working Paper no. 211, International Monetary Fund, Washington DC.

IMF 2004. Three Current Policy Issues. World Economic Outlook (September). Available at: http://www.imf.org/external/pubs/ft/weo/2004/02/pdf/chapter2.pdf

IMF 2011. Housing Finance and Financial Stability-Back to Basics?. Available at: http://www.imf.org/external/pubs/ft/gfsr/2011/01/pdf/chap3.pdf

Jarque, C.M. and Bera, A.K. 1980. Efficient Tests for Normality, Homoscedasticity and Serial Independence of Regression Residuals. Economics Letters 6: 255-9.

Jarque, C.M. and Bera, A.K. 1981. Efficient Tests for Normality, Homoscedasticity and Serial Independence of Regression Residuals: Monte Carlo Evidence. Economics Letters 7: 313-18. 
Kwiatkowski, D., Phillips, P.C.B., Schmidt, P., and Shin, Y. 1992. Testing the Null Hypothesis of Stationarity against the Alternative of A Unit Root: How Sure Are We that Economic Time Series Have a Unit Root?. Journal of Econometrics 54: 159-78.

Laibson, D. and Mollerstrom, J. 2010. Capital Flows, Consumption Booms and Assets Bubbles: A Behavioural Alternative to the Savings Glut Hypothesis. NBER Working Paper no. 15759, National Bureau of Economic Research, Cambridge MA.

Lee, J. and Stazicich, M.C. 2003. Minimum LM Unit Root Test with Two Structural Breaks. Review of Economics and Statistics 85: 1082-9.

Mian, A. and Sufi, A. 2009. The Consequences of Mortgage Credit Expansion: Evidence from the 2007 Mortgage Default Crisis. Quarterly Journal of Economics 124: 1449-1496.

Miller, N., Peng, L. and Sklarz, M. 2011. House Prices and Economic Growth. Journal of Real Estate Finance and Economics 42: 522-41.

Milne, A. 1991. Incomes, Demography and the UK House Prices. Discussion Paper no. 3990, LBS Centre for Economic Forecasting, London.

Muellbauer, J. and Cameron, G. 1998. Some Home Truths. Housing Outlook, $18^{\text {th }}$ August.

Nelson, C.R. and Plosser, C. 1982. Trends and Random Walks in Macroeconomic Time Series: Some Evidence and Implications. Journal of Monetary Economics 10: 139-162.

Pesaran, M.H. and Shin, Y. 1999. An Autoregressive Distributed Lag Modelling Approach to Cointegration Analysis. In: Strom, S., Holly, A. and Diamond, P. (eds), Centennial Volume of Rangar Frisch, Cambridge University Press, Cambridge.

Pesaran, M.H., Shin, Y., and Smith, R.J. 2001. Bounds Testing Approaches to the Analysis of Level Relationships. Journal of Applied Econometrics 16: 289-26.

Phillips, P.C.B. and Perron, P. 1988. Testing for a Unit Root in Time Series Regression. Biometrika, 75: 335-46.

Poterba, J.M. 1992. Taxation and Housing Markets. In J.B. Shoven and J. Whalley (eds), Canada-U.S. Tax Comparisons, University of Chicago Press, Chicago.

Poterba, J.M. 1994. Public Policy and Housing in the United States. In Y. Noguchi and J.M. Poterba (eds), Housing Markets in the U.S. and Japan, University of Chicago Press Chicago.

Punzi, M.T. 2013. Housing Market and Current Account Imbalances in the International Economy. Review of International Economics 21: 601-13.

Rebollo, A. 2001. La Estructura de Consumo en España. Instituto Nacional del Consumo, Madrid.

Reinhart, C.M. and Rogoff, K.S. 2009. This Time Is Different: Eight Centuries of Financial Folly. Princeton University Press, Princeton.

Renaud, B. 1995. The 1985-94 Real Estate Cycle: Its Causes and Consequences. Policy Research Working Paper Series 1452, The World Bank, Washington DC. 
Shiller, R.J. 2007. Understanding Recent Trends in House Prices and Home Ownership. NBER Working Paper no. 13553, National Bureau of Economic Research, Cambridge MA.

Sims, C. (1972), "Money, Income and Causality”, American Economic Review, 62: 540-552.

Taylor, J.B. 2009. Getting off Track: How Government Actions and Interventions Caused, Prolonged, and Worsened the Financial Crisis. Hoover Institution Press, Stanford.

Terrones, M.E. and Otrok, C. 2004. The Global House Price Boom. World Economic Outlook, September, International Monetary Fund, Washington, DC.

The Economist 2012. Global House Prices. Downdraft. 31 March.

United Nations 2011. World Population Prospects: The 2010 Revision. United Nations, Department of Economic and Social Affairs, Population Division, New York.

White, H. 1980. A Heteroskedasticity-Consistent Covariance Matrix Estimator and a Direct Test for Heteroskedasticity. Econometrica 48: 817-38.

Yang, T.T., Buist, H., and Megbolugbe, I.F. 1998. An Analysis of the Ex Ante Probabilities of Mortgage Prepayment and Default. Real Estate Economics 26: 651-76.

\section{APPENDIX}

TABle 3: House PRICE Relationships: DiAgnOSTICS/STATISTICS

\begin{tabular}{|c|c|c|c|c|c|c|c|}
\hline \multicolumn{8}{|c|}{ Diagnostic/Statistics } \\
\hline & LM (1) & LM (2) & Jarque-Bera & White & White X & $\mathrm{ARCH}(1)$ & $\mathrm{ARCH}(2)$ \\
\hline Australia & $0.03(0.8566)$ & $0.01(0.9840)$ & $1.27(0.5279)$ & $2.71(0.0447)$ & $1.18(0.3390)$ & $1.91(0.1748)$ & $3.36(0.0457)$ \\
\hline Belgium & $2.90(0.0989)$ & $1.43(0.2536)$ & $0.34(0.8418)$ & $0.98(0.4728)$ & $1.29(0.3024)$ & $0.52(0.4733)$ & $0.56(0.5715)$ \\
\hline Canada & $0.04(0.8336)$ & $1.27(0.2916)$ & $0.11(0.9452)$ & $2.32(0.0746)$ & $0.83(0.6254)$ & $5.80(0.0208)$ & $3.35(0.0457)$ \\
\hline Denmark & $0.14(0.7040)$ & $0.15(0.8588)$ & $1.12(0.5691)$ & $0.78(0.5103)$ & $1.11(0.3781)$ & $0.01(0.8931)$ & $0.08(0.9210)$ \\
\hline Finland & $0.39(0.5331)$ & $0.94(0.3970)$ & $1.08(0.5802)$ & $1.07(0.3507)$ & $2.40(0.0557)$ & $3.36(0.0741)$ & $1.57(0.2205)$ \\
\hline France & $0.89(0.3497)$ & $0.52(0.5946)$ & $0.16(0.9199)$ & $0.70(0.5576)$ & $0.97(0.4766)$ & $0.01(0.9038)$ & $0.05(0.9456)$ \\
\hline Germany & $0.33(0.5668)$ & $0.37(0.6878)$ & $0.01(0.9934)$ & $0.81(0.6073)$ & $1.13(0.4021)$ & $0.09(0.7569)$ & $2.72(0.0792)$ \\
\hline Ireland & $1.06(0.3091)$ & $1.86(0.1688)$ & $1.28(0.5267)$ & $0.83(0.4808)$ & $0.66(0.7361)$ & $0.77(0.3826)$ & $1.29(0.2852)$ \\
\hline Italy & $0.37(0.5434)$ & $0.78(0.4676)$ & $0.15(0.9263)$ & $1.93(0.0739)$ & $2.38(0.0409)$ & $3.25(0.0789)$ & $5.20(0.0102)$ \\
\hline Japan & $0.22(0.6409)$ & $1.83(0.1763)$ & $0.87(0.6462)$ & $1.08(0.3926)$ & $0.73(0.7314)$ & $1.66(0.2046)$ & $1.98(0.1520)$ \\
\hline Netherlands & $0.10(0.7495)$ & $1.03(0.3667)$ & $0.69(0.7064)$ & $0.63(0.7837)$ & $1.89(0.0789)$ & $0.50(0.4813)$ & $0.32(0.7275)$ \\
\hline New Zealand & $3.55(0.0675)$ & $1.98(0.1523)$ & $0.63(0.7270)$ & $0.44(0.7771)$ & $0.58(0.8541)$ & $0.00(0.9361)$ & $0.30(0.7416)$ \\
\hline Norway & $0.21(0.6427)$ & $0.11(0.8950)$ & $0.27(0.8732)$ & $2.59(0.0519)$ & $1.62(0.1353)$ & $0.50(0.4821)$ & $0.73(0.4866)$ \\
\hline Spain & $2.91(0.0973)$ & $1.41(0.2573)$ & $5.14(0.0762)$ & $0.37(0.9093)$ & $0.33(0.9882)$ & $0.21(0.6469)$ & $0.22(0.8030)$ \\
\hline Sweden & $3.21(0.0820)$ & $1.56(0.2250)$ & $0.39(0.8198)$ & $1.48(0.2113)$ & $1.43(0.2491)$ & $0.97(0.3287)$ & $0.39(0.6755)$ \\
\hline UK & $0.07(0.7837)$ & $1.36(0.2689)$ & $0.21(0.8971)$ & $2.56(0.0310)$ & $1.58(0.1452)$ & $0.07(0.7837)$ & $0.28(0.7538)$ \\
\hline US & $3.31(0.0768)$ & $2.11(0.1349)$ & $1.86(0.3940)$ & $0.72(0.5444)$ & $0.72(0.5444)$ & $0.52(0.4715)$ & $1.039(0.3638)$ \\
\hline
\end{tabular}

Note: Numbers in parentheses indicates the $p$-value for each test. 